\title{
NELAYAN BRONDONG DALAM KONSTRUKSI KEBERAGAMAAN (STUDI FENOMENOLOGI PADA MASYARAKAT NELAYAN DI KECAMATAN BRONDONG, KABUPATEN LAMONGAN)
}

\section{RELIGIOUS CONSTRUCTION OF BRONDONG FISHERMEN (PHENOMENOLOGY STUDY ON FISHERMEN SOCIETY IN KECAMATAN BRONDONG, KABUPATEN LAMONGAN)}

\author{
Nike Kusumawanti \\ Program Studi Sosiologi, Fakultas Ilmu Sosial dan Ilmu Politik, Universitas Brawijaya \\ nike_kusumawanti@yahoo.com
}

\begin{abstract}
Abstrak
Studi ini bertujuan untuk memahami esensi keberagamaan nelayan dengan cara: (1) Menjelaskan transformasi ideologi dan agama yang terjadi di Brondong dari masa ke masa, (2) Memahami proses konstruksi sosial masyarakat nelayan Brondong dalam memaknai agama. Kedua permasalahan tersebut akan didekati dengan perspektif Konstruksi Sosial PeterL.Berger dan Thomas Luckmann dan Praktik Sosial Pierre Bourdieu, dengan pendekatan fenomenologi.Dari hasil analisis diperoleh kesimpulan sebagai berikut.Pertama, transformasi ideologi dan agama yang terjadi pada masa Kerajaan Mataram hingga pergerakan sosial pada tahun 1965 berpengaruh pada dinamika ideologi dan keagamaan masyarakat nelayan Brondong. Kedua, konstruksi sosial atas religiusitas nelayan menunjukkan adanya perbedaan keberagamaan di level struktural dan kultural karena terjadi kompetisi kekuatan modal sosial dan modal simbolik yang dipertarungkan dalam ranah masyarakat nelayan Brondong.
\end{abstract}

Kata kunci: konstruksi sosial, religiusitas nelayan, transformasi ideologi dan agama.

\section{Abstract}

This study aims to understand the religious essence of fishermen by: (1) Explaining the ideological and religious transformations that occurred in Brondong from time to time, (2) Understanding the social construction process of the Brondong fishermen community in interpreting religion. Both issues will be approached with the perspective of PeterL.Berger and Thomas Luckmann's Social Construction and Pierre Bourdieu's Social Practice, with a phenomenological approach.From the analysis results obtained the following conclusion. First, the transformation of ideology and religion that occurred during the Mataram Kingdom until the social movement in 1965 influenced the ideological and religious dynamics of the fishing community Brondong. Second, the social construction of the religiosity of fishermen shows the existence of religious differences in the structural and cultural levels due to competition of social capital and symbolic capital which is fought in the realm of fishing society of Brondong.

Keywords: social construction, religiusity of fishermen, transformation of ideology and religion.

\section{Pendahuluan}

Diskursus keagamaan kontemporer menjelaskan bahwa "agama" ternyata mempunyai banyak wajah (multifaces). Pada konteks kehidupan beragama sehari-hari, terkadang sulit untuk membedakan antara sesuatu yang murni agama dan hasil pemikiran atau interpretasi dari agama. Sesuatu yang murni agama, berarti berasal dari Tuhan, absolut dan mengandung nilai sakralitas. Hasil pemikiran agama, berarti berasal dari selain Tuhan (manusia), bersifat temporal, berubah, dan tidak sakral. Pada aspek realisasi, muncul kesulitan membedakan keduanya karena terjadi tumpang-tindih dan terjadi pencampuradukan makna antara agama dengan pemikiran agama, baik sengaja atau tidak. Perkembangan selanjutnya, hasil pemikiran agama kadang-kadang telah berubah menjadi agama itu sendiri, sehingga ia disakralkan dan dianggap berdosa bagi yang berusaha merubahnya (Kamiruddin, 2011). Hal ini tersirat dalam tesis Maliki (2006) yang mengungkapkan bahwa pemahaman, artikulasi, dan perilaku keberagamaan (religiusitas) manusia tidak pernah seragam. Oleh karena itu, fenomena keberagamaan manusia tidak hanya cukup dipahami dengan pendekatan teologis semata tetapi perlu didekati, diteliti, 
dipahami dan dikritik melalui pendekatan yang bersifat sosiologis.

Pendekatan sosiologis mengenai agama diawali oleh Emile Durkheim (1961) yang mengungkap bahwa agama mempunyai fungsi kohesi sosial, lalu Marx dan Engels (1964)yang menganggap bahwa agama adalah candu masyarakat dan Weber (1969) tentang peran positif agama dalam perubahan sosial. Bila Durkheim, Marx dan Weber sedikit simplistis dalam menjelaskan fungsi dan peran agama maka sosiologi pengetahuan Berger dan Luckmann (1991) mencoba menjelaskan fenomena agama secara berbeda dengan melihat realitas historis dan bangunan spesisfik sosiokultural. Sosiologi pengetahuan Berger dan Luckmann menganalisis apa saja yang dianggap sebagai pengetahuan dalam masyarakat awam. Sejauh mana semua "pengetahuan" manusia itu dikembangkan, dialihkan, dan dipelihara dalam berbagai situasi sosial, maka sosiologi pengetahuan berusaha memahami bagaimana proses-proses itu dilakukan sedemikian rupa, sehingga pada akhirnya terbentuklah "kenyataan" yang dianggap sudah sewajarnya oleh orang- orang awam (Berger dan Luckmann, 1991: 4). Dengan kata lain, bahwa sosiologi pengetahuan menekuni analisa pembentukan kenyataan oleh masyarakat (social construction of reality).

Studi ini hendak melihat fenomena keagamaan masyarakat nelayan di Brondong dengan menggunakan pendekatan sosiologi pengetahuan atau konstruksi sosial Peter. L. Berger dan Luckmann. Di samping itu, kajian ini juga mencoba menemukan relasi antara agama dan kekuasaan kiai dengan mengikutsertakan analisis strategi modal dari Pierre Bourdieu.

Sebagaimana diketahui bahwa nelayan lebih tunduk pada otoritas tokoh agama seperti kiai dan ulama daripada aparat pemerintahan. Menurut Kusnadi (2006), pemimpin-pemimpin informal keagamaan dalam masyarakat nelayan memiliki peranan yang strategis. Pemimpinpemimpin informal ini merupakan tempat mengadu, berkonsultasi, dan meminta perlindungan bagi nelayan dalam mengatasi masalah-masalah kehidupan yang mereka hadapi setiap saat. Kedudukan dan peranan pemimpin informal akan semakin kokoh jika mereka memiliki sumber daya ekonomi dan akses politik yang luas (Kusnadi, 2006).

Sekalipun masyarakat nelayan dihadapkan pada sejumlah keterbatasan kemampuan sosial- ekonomi, jika pemimpin-pemimpin informal mencanangkan program pembangunan ibadah atau madrasah keagamaan Islam maka rencana ini akan disambut secara positif dan dilaksanakan dengan sebaik-baiknya. Sebaliknya, jika pemerintah desa merencanakan program pembangunan kantor balai dusun dan meminta tenaga dan dana dari masyarakat nelayan, maka "sudah dapat dipastikan" bahwa perwujudan rencana tersebut tidak memperoleh dukungan kongkret dari masyarakat (Kusnadi, 2006).

Kelurahan Brondong sebagai lokus penelitian tulisan ini merupakan salah satu kelurahan di pesisir kawasan Pantura dan merupakan bagian wilayah Kecamatan Brondong, Kabupaten Lamongan, Propinsi Jawa Timur. Kelurahan Brondong sesungguhnya merupakan tipologi desa nelayan, tetapi berkarakteristik permukiman perkotaan karena dilengkapi dengan sejumlah pusat aktivitas ekonomi dan perdagangan, seperti Tempat Pelelangan Ikan Brondong, Pelabuhan Perikanan Nusantara III, Pabrik Es, Bank Umum dan Bank Daerah, Perum Pegadaian, pasar, mini supermarket, showroom motor, dan lain sebagainya. Dengan kondisi geografis seperti ini memungkinkan gaya hidup masyarakatnya juga mempunyai ciri khas masyarakat perkotaan yang mempunyai etos kerja tinggi, konsumtif, pragmatis dan sekuler.

Mata pencaharian utama masyarakat Brondong adalah nelayan, baik yang disebut sebagai nelayan darat maupun nelayan laut. Nelayan laut dalam arti mencari ikan di laut sebagaimana makna nelayan pada umumnya, sedangkan nelayan darat mempunyai arti nelayan yang memiliki modal ekonomi untuk membiayai semua perjalanan nelayan selama melakukan aktivitas di laut.

Secara sosial-keagamaan, basis komunitas keagamaan masyarakat nelayan Brondong secara struktural adalah Islam yang berafiliasi Muhammadiyah, sedangkan Islam Nahdatul Ulama (NU) hanya merupakan golongan minoritas. Meskipun demikian bukan berarti masyarakatnya meninggalkan sejumlah tradisi peninggalan nenek moyang. Hal Ini dapat dibuktikan dengan masih banyak dijumpai sejumlah upacara petik laut dan tutup playang beserta seni tayuban, tradisi slametan lingkaran hidup (kelahiran, pernikahan, dan kematian), slametan kalenderikal, slametan malam jum'at wage dan tradisi manganan yang ditujukan 
kepada leluhur Desa Brondong yaitu Mbah Buyut Sentono.

Penelitian yang dilakukan oleh Mulkhan juga menggambarkan fenomena Muhammadiyah serupa. Menurut Mulkhan (1999), Muhammadiyah memang merupakan gerakan keagamaan anti takhayul, bidh'ah, dan churafat (TBC) tetapi ketika berada di tangan kaum petani juga mengalami naturalisasi. Gerakan Muhammadiyah belumlah tuntas, sehingga Muhammadiyah di tangan petani juga memberikan gambaran bahwa belum semua orang Muhammadiyah melakukan Islam sebagaimana penafsiran para elitnya tentang Islam (Mulkhan, 1999). Sebagaimana dengan masyarakat nelayan di Brondong. Muhammadiyah diBrondong hanya ada pada level struktural saja sedangkan level kultural masih memegang nilai- nilai nahdliyin (NU).

Otoritas kiai dan ulama Muhammadiyah juga berperan penting dalam hal "pemaksaan" nilai-nilai Muhammadiyah dalam masyarakat nelayan Brondong. Penghapusan tradisi tayuban dan larung kepala kerbau dalam upacara tutup playang, pembangunan masjid dan mushola Muhammadiyah yang terkesan dipaksakan, serta ceramah-ceramah agama yang cenderung mendiskreditkan komunitas NU menjadi bukti atas pemaksaan nilai-nilai tersebut.

Permasalahan yang menjadi fokus penelitian ini adalah makna agama sebagai hasil konstruksi sosial masyarakat lokal tidak hanya dibangun dengan memperhatikan konteks budaya saja, tetapi juga dipengaruhi oleh kondisi sosial politik-ekonomi, sosiohistoris, dan juga relasi kekuasaan yang berada di dalamnya, karena konstruksi sosial pada dasarnya tidak berasal dari ruang hampa. Hal ini tergantung bagaimana agama dikonstruksi oleh masyarakat di satu pihak dan penguasa di pihak yang lain.

\section{Metode Penelitian}

Sesuai dengan asumsi metodologis yang diungkap di depan, agar bisa memahami konstruksi sosial makna agama nelayan, maka dalam penelitian ini digunakan analisis yang bersifat kualitatif. Pendekatan yang dipakai dalam penelitian ini adalah fenomenologi yang bertujuan untuk berusaha memahami arti peristiwa dan kaitannya terhadap orang-orang biasa dalam situasi tertentu (Moleong, 2000:9). Fenomenologi akan berusaha memahami pemahaman informan terhadap fenomena yang muncul dalam kesadarannya, serta fenomena yang dialami oleh informan dan dianggap sebagai entitas sesuatu yang ada dalam dunia (Sukidin, 2002:32).

Tulisan ini menentukan informan dengan tekniksnowball (pengambilan informan seperti bola salju). Dalam teknik ini, pengumpulan data dimulai dari beberapa orang yang memenuhi kriteria untuk dijadikan informan. Orang-orang yang ditunjukkan ini kemudian dijadikan anggota sampel dan selanjutnya diminta menunjukkan orang lagi yang memenuhi kriteria menjadi anggota sampel. Demikian prosedur ini dilanjutkan sampai jumlah anggota sampel yang diinginkan terpenuhi.

Informan yang diwawancara seluruhnya oleh peneliti pada saat pengumpulan data adalah sebanyak 18 orang tetapi oleh peneliti dibagi menjadi dua kategori. Kategori pertama adalah informan utama yaitu sebanyak 9 orang, 7 orang adalah nelayan dan 2 orang adalah tokoh agama yang dimasukkan dalam analisa data, sedangkan kategori kedua adalah informan pendukung yang tidak dimasukkan dalam analisa data tetapi dijadikan sebagai data pendukung.

Untuk keperluan pengumpulan data, peneliti melakukan wawancara secara mendalam (depth interview) dengan menggunakan pedoman wawancara (guide interview) terhadap informan yang telah dipilih sebelumnya. Setelah wawancara, kemudian hasilnya diubah dalam bentuk catatan. Proses pengumpulan data primer yang dilakukan oleh peneliti di Brondong membutuhkan waktu 3 bulan yang terbagi menjadi 3 periode terhitung sejak bulan September hingga Desember tahun 2008, sedangkan proses observasi data sudah dilakukan peneliti sebelumnya.

\section{Agama, Ideologi, dan Kekuasaan menurut PeterL. Berger dan Pierre Bourdieu}

Mengikuti konsep Sosiologi Pengetahuan yang dikembangkan oleh Peter L. Berger dan Luckmann (1966, 1990), realitas sosial berupa pengetahuan yang bersifat keseharian seperti konsep, kesadaran umum, dan wacana publik merupakan hasil konstruksi sosial. Kenyataan itu sendiri bersifat plural, dinamis, dan dialektis. Lebih lanjut, agama dipandang sebagai konstruksi sosial, berarti menjadikan agama sebagai proses sosial yang melibatkan eksternalisasi, objektivasi, dan internalisasi.

Dalam perspektif konstruksi sosial, pengetahuan agama sebagai realitas tidak pernah 
merupakan realitas tunggal yang bersifat statis dan final, melainkan merupakan realitas plural yang bersifat dinamis dan dialektis. Kenyataan bersifat plural karena adanya relativitas sosial dari apa yang disebut "pengetahuan" dan "kenyataan" (Susan, 2007).

Salah satu pembahasan terhadap agama melalui konsep Sosiologi Pengetahuan, dilakukan oleh Peter L Berger dalam bukunyaKabar Angin dari Langit (Makna Teologi dalam Masyarakat Modern).Berger memberikan pemahaman bahwa ada pengaruh timbal balik antarberbagai sistem makna, yang mencakup juga berbagai sistem agama, dan pengalaman sosial maupun perorangan yang coba ditafsirkan oleh manusia berdasarkan sistem-sistem semacam itu (Sastrapratedja dalam Berger, 1994).

Menurut Berger, secara historis, agama merupakan salah satu bentuk legitimasi yang paling efektif. Agama merupakan semesta simbolik yang memberi makna pada kehidupan manusia dan yang memberikan penjelasan yang paling komprehensif tentang realitas seperti kematian, penderitaan, tragedi, dan ketidakadilan (Berger, 1994). Namun, agama sebagai konstruksi sosial pada akhirnya meniscayakan apa yang disebut kebenaran hakiki dalam sebuah agama. Kebenaran dalam sebuah agama adalah relativitas pada sebuah realitas tergantung pada konteks sosial budaya masyarakat tersebut. Seperti ilustrasi Berger berikut, apa yang "nyata" bagi seorang biarawan Tibet mungkin saja tidak "nyata" bagi seorang pengusaha Amerika; "pengetahuan" seorang penjahat berbeda dengan "pengetahuan" ahli kriminologi (Berger, 1990).

Realitas pluralisme konstruksi sosial dalam masyarakat menumbuhkan persaingan untuk berebut pengaruh dan menjadi konstruksi dominan. Pada akhirnya, fenomena kekuasaan ikut terlibat, dan dari sinilah kemudian fenomena ideologi muncul. Menurut Berger, ketika suatu definisi tertentu mengenai kenyataan pada akhirnya dikaitkan dengan suatu kepentingan kekuasaan yang konkret, ia bisa dinamakan ideologi. Pengetahuan konflik agama yang turun dalam bentuk yang antagonis, bersifat doktrin, merupakan bentuk pengetahuan yang dibentuk oleh kekuasaan dalam masyarakat.

Dalam perspektif Berger, kekuasaan mempunyai peranan penting dalam kehidupan sosial. Sehingga menurutnya, kekuasaan dalam masyarakat mencakup kekuasaan untuk menetapkan proses-proses sosialisasi yang sifatnya menentukan dan, dengan demikian, kekuasaan untuk membuat kenyataan. Jelasnya, benar dan salah, baik dan buruk, menjadi wewenang kekuasaan dalam menentukannya.

Bourdieu menjelaskan rute pergulatan agen dalam ruang sosial dan arena tertentu sebagai bagian spesifik dari ruang sosial dalam konsepnya tentang lintasan atau trajectory atau biografi yang dikonstruksikan. Bourdieu menggunakan istilah-istilah tersebut secara bergantian untuk menyebut satu pemahaman yang sama. Trajectory adalah:

\begin{abstract}
“....serangkaian gerak suksesif seorang agen di dalam ruang yang terstruktur (berhierarki), yang bisa mengalami penggantian dan distorsi, atau lebih tepatnya, di dalam struktur distribusi jenis-jenis modal berbeda yang dipertaruhkan di dalam arena, modal ekonomi dan modal konsekrasi spesifik" (Bourdieu dalam Karnanta, 2013).
\end{abstract}

Dengan definisi serupa itu, Bourdieu sesungguhnya menunjukkan bahwa pergulatan agen merupakan suatu proses ketika segenap modal distribusikan dengan cara-cara tertentu demi "memenangkan" atau meraih sesuatu yang menjadi taruhan dalam ruang danarena tersebut. Implikasi dari definisi tersebut, ruang dan arena bersifat cair dalam arti bisa berubah dan diubah, bukan sesuatu yang tetap dan konstan. Perubahan dalam ruang sosial dan arena tersebut terjadi salah satunya karena melemahnya agen-agen yang sebelumnya menempati posisi sebagai yangdominan dalam arena tersebut mengalami penuaansosial; dan di saat yang sama, agen-agen muda, dengan segala modal yang dimilikinya, berusaha merebut posisi itu. "Gerak-gerak ini, yang mendefinisikan penuaan sosial (social ageing) terdiri atas dua susunan. Mereka bisa dibatasi kepada salah satu sektor arena dan terletak di sepanjang nol atau negatif modal spesifik; atau mereka malah menyebabkan perubahan sektor dan rekonversi (pengalihan bentuk) modal spesifik tertentu menjadi jenis modal lain" (dalam Karnanta, 2013).

Lebih jauh, trajectory agen dalam ruang sosial dan arena tidak bisa terlepas dari strategi sebagai cara memposisikan diri sekaligus mendistribusikan modal-modal yang ia miliki. Bourdieu (Karnanta, 2013) menyebut "strategi adalah produk dari rasa praktis seperti halnya permainan buat suatu permainan yang partikular dan historis." Strategi terkait langsung dengan praktik seorang agen dalam ruang sosial dan arena tertentu, berdasarkan modal-modal yang 
dimiliki agen. Lebih jauh, Bourdieu menyebut 'strategi' untuk menjelaskan tiga ide terkait praktik agen yakni: "(1) Ide tentang perjuangan demi pengakuan sebagai dimensi fundamental kehidupan sosial. Perjuangan ini merupakan perjuangan atas akumulasi modal. Oleh karena itu, pasti ada suatu logika spesifik tentang akumulasi modal simbolik, seperti modal yang dibangun berdasarkan pengetahuan dan pengenalan; (2) Ide tentang strategi - seperti halnya orientasi praktik-sebagai sesuatu yang tidak sadar atau tidak terkalkulasi maupun terdeterminasi secara mekanis. Ia merupakan produk intuitif "pengetahuan" tentang aturanaturan permainan; (3) Ide tentang adanya sebuah logika praktik-yang rinciannya bergantung pada tempat dan waktu yang spesifik atau mungkin, tentu saja, bergantung pada suatu urutan peristiwa di dalam waktu" (dalam Mahar, 2009: 22).

Bourdieu (2006:131) merinci varian strategi tersebut menjadi strategi rekonversi modal atau penukaran kembali dan strategi reproduksi. Strategi rekonversi modal mengacu pada mobilitas agen dalam ruang sosial berdasarkan pertukaran dan pembentukan modalmodal yang dimilikinya ke dalam modal-modal spesifik yang berlaku dalam arena tersebut; sedangkan strategi reproduksi mengacu pada cara-cara agen mengolah, memperluas, mempertahankan, dan mengakumulasi modal-modal yang dimilikinya.

Haryatmoko (2003:15) menjelaskan konsep strategi Bourdieu tersebut sesungguhnya dipahami sebagai (a) Strategi investasi ekonomi yang terkait dengan menambah serta mempertahankan modal ekonomi; (b) Strategi investasi simbolik, mempertahankan dan meningkatkan pengakuan sosial yang didapat; (c) Strategi investasi biologis, yakni kontrol pengaturan jumlah keturunan; (d) Strategi pewarisan, terkait dengan modal ekonomi yang dipandang sebagai modal yang signifikan dalam arena kekuasaan; (e) Strategi pendidikan, yakni praktik yang mengarah pada usaha menghasilkan pelaku sosial yang memiliki keahlian tertentu. Dengan pengertian di atas, Bourdieu sesungguhnya menunjukkan bahwa konsep trajectory dan strategi merupakan titik vital teori arena produksi kultural yang dibangunnya. Strategi selalu inheren dalam praktik seorang agen yang mana praktik dipahami sebagai keseluruhan tindakan yang melibatkan modal, habitus, dan taruhan-taruhan dalam suatu ranah.
Tokoh kiai Muhammadiyah dalam studi ini dilihat sebagai seorang agen dalam pandangan Bordieu yang memperjuangkan modal-modal yang dimiliki di dalam ranah masyarakat Brondong. Menurut Sudarmanto (1987), agama sebagai sistem sosial berfungsi sebagai pemberi legitimasi bagi kelompok-kelompok sosial dalam masyarakat. Bagi kelompok penguasa, agama membenarkan kedudukannya. Bagi kelompok bawah, agama memberikan pembenaran atau melegitimasikan perjuangan kelompok tersebut. Agama dalam hal ini menjadi ideologi dengan membenarkan situasi yang ada sehingga dengan demikian melestarikan status quo kelompok penguasa.

\section{Sosiohistoris Keberagamaan Nelayan Brondong: Desa Pesisir yang Selalu Berubah}

\section{- Masa Kerajaan Mataram: Peran Mbah Buyut Sentono}

Sejarah Jawa Timur pada zaman dulu banyak membicarakan kawasan pantai utara Jawa Timur berkaitan dengan peranannya sebagai pelabuhan kuno. Pelabuhan tersebut berfungsi sebagai pusat perdagangan yang bertaraf internasional, karena tidak hanya didatangi oleh pedagang-pedagang di tingkat lokal tetapi juga pedagang dari Cina, India, Timur Tengah, Gujarat, dan bangsa-bangsa lain, khususnya di kawasan Asia. Pelabuhan tersebut antara lain pelabuhan pantai Kambang Putih di Tuban, pelabuhan Sedayulawas di dekat Brondong, Pelabuhan Gujaratan, pelabuhan Gresik, pelabuhan Ujung Galuh di Suropringgo (Surabaya), pelabuhan Yuwana di Lasem yang pada saat itu masih masuk dalam propinsi Jawa Timur.

Pelabuhan Sedayulawas yang terletak di dekat desa Brondong, mempunyai arti penting di pantai utara Jawa sebagai pintu gerbang Kerajaan Kediri menuju negeri di luar pulau Jawa. Pelabuhan ini merupakan andalan pada masa kerajaan Majapahit dan kerajaan Demak Bintoro. Namun, pada zaman Kerajaan Pajang, pelabuhan ini menurun fungsinya sehingga hanya menjadi pelabuhan rakyat hingga kini (Chambali, 2001).

Syahbandar yang menguasai pelabuhan Sedayulawas silih berganti di antara tokoh-tokoh yang ditunjuk. Pada tahun 1630 pada saat kedatangan bangsa-bangsa Eropa di pelabuhan Sedayulawas telah dikenal seorang Syahbandar bernama Ki Gedhe Buyut yang juga seorang pemimpin masyarakat Brondong. Setelah wafat 
pada tahun 1639, Ki Gedhe Buyut dimakamkan di tanah Sentono sebelah barat Masjid Sentono dengan panggilan Mbah Buyut Sentono. Setelah Ki Gedhe Buyut wafat, syahbandar Brondong digantikan oleh adiknya sendiri yang bernama Ki Lanang Dangiran atau yang dikenal sebagai Joko Brondong, seorang pangeran dari kerajaan Blambangan (Chambali, 2001).

Pada masa ini, kawasan Pambon, Brondong, Blimbing, dan Paciran bagian barat masih menjadi wilayah Kadipaten Tuban. Sementara itu, Tunggul, Drajat, Banjarwati, Kranji, Paloh, Tlogosandang, Solokuro ke timur menjadi bagian wilayah Kadipaten Sidayu.

Perkembangan desa Brondong terjadi ketika pelabuhan Sedayulawas yang awalnya menjadi markas pasukan marinir, juga dipakai menjadi lintas barang perdagangan yang ramai sebab ada jalan kuno menuju pedalaman melalui Brondong-Laren ke selatan menembus pegunungan Kendeng Timur. Ketika Ki Lanang Dangiran menjadi penguasa dan Syahbandar maka ada upaya mengembangkan pelabuhan kecil untuk pendaratan ikan di Brondong. Pelabuhan Ikan Brondong kini menjadi Pelabuhan Nusantara III yang besar seperti di Muncar, Bagan Siapi-api, dan Pekalongan.

Dilihat dari aspek sosial keagamaan, kawasan pantai Brondong sampai Blimbing dan Paciran tunduk pada pengaruh seorang kiai yang bernama Kiai Kendil Wesi yang bermukim di Paciran. Kiai Kendil Wesi adalah seorang ulama yang meneruskan dakwah Sunan Sendang Duwur dan merupakan guru dari Ki Lanang Dangiran atau Joko Brondong.

Ki Lanang Dangiran mendapatkan berbagai ilmu agama dan tasawuf dari kiai Kendil Wesi. Di samping itu, Ki Lanang mampu mendapatkan kekuatan untuk mengalahkan musuh serta ahli dalam hal pengobatan penyakit. Kedigdayaan $\mathrm{Ki}$ Lanang juga dibuktikan dalam olah batin dan raga serta bersemedi di tengah laut pantai Brondong di dalam bronjong ${ }^{1}$ selama berbulanbulan hingga badannya terendam air laut dan ditumbuhi lumut dan kerang-kerangkecil berwarna putih di seluruh tubuh seperti brondong ${ }^{2}$ menempel.

\footnotetext{
${ }^{1}$ Bronjong adalah tempat pencari ikan di laut atau bisa juga digunakan untuk wadah gamelan.

${ }^{2}$ Dalam bahasa Jawa, brondong artinya biji jagung yang dikeringkan kemudian digoreng atau biasa disebut popcorn.
}

Menurut legenda setempat, inilah nama asal-usul desa Brondong.

Menurut Achmad Chambali (2001), Pangeran Lanang Dangiran bermukim di dekat Sentono Brondong sebagai pemimpin masyarakat Brondong yang menjadi teladan. Beliau juga dikenal sebagai ulama yang menyiarkan Islam dengan sabar dan penuh kasih sayang kepada rakyatnya sehingga masyarakat Brondong menyebutnya Kiai Ageng Brondong atau Kiai Lanang Dangiran.

Di sisi lain, masyarakat desa Brondong saat ini lebih mengenal Ki Gedhe Buyut Sentono atau Mbah Buyut Sentono. Menurut Pak Mustaji, modin di daerah Sentono, mengungkapkan bahwa Mbah Buyut Sentono, mengajarkan agama Islam kepada masyarakat Brondong dan membuat sumur dan masjid walaupun belum jadi. Bahkan, sebagian masyarakat Brondong meyakini bahwa mbah Buyut Sentono adalah seorang waliullah karena membuat masjid tiban atau masjid yang turun dari langit dan tiba-tiba jadi.

Hal tersebut juga dibenarkan oleh Pak Mardaub, ketua Rukun Nelayan Brondong, yang mengungkapkan bahwa di sekitar masjid Sentono atau masjid Al-Jihad terdapat gundukan tanah yang lebih tinggi dari tanah di sekitarnya dan diyakini bahwa tanah tersebut adalah bekas masjid yang tidak jadi. Disamping itu, Pak Mardaub juga menambahkan, jika masyarakat ingin melihat Mbah Sentono harus bersemedi terlebih dahulu.

\section{- Masa Partai Komunis Indonesia (PKI)}

Kehidupan keagamaan nelayan Brondong memang mengalami pasang surut. Setelah di depan dijelaskan bagaimana kehidupan masyarakat Brondong pada masa Mbah Sentono yang hidup pada masa kerajaan Mataram, pada bagian ini akan dijelaskan tentang kehidupan masyarakat nelayan pada masa sebelum G30S/PKI 1965 atau pada saat PKI melebarkan sayap ideologinya ke seluruh Indonesia, khususnya di wilayah Brondong.

Pada masa PKI, wilayah Brondong ${ }^{3}$ terutama daerah Sentono merupakan basis kegiatan dan persebaran PKI yang terbesar di wilayah Kecamatan Brondong. Padahal secara geografis, daerah ini diapit oleh dua daerah yang terkenal mempunyai basis keagamaan sangat

\footnotetext{
${ }^{3}$ Yang dimaksud adalah Kelurahan Brondong.
} 
kuat, yaitu Desa Belimbing dan Desa Sedayulawas.

Kecintaan masyarakat Brondong terhadap seni tradisional dan tradisi menjadi salah satu sebab mengapa PKI mudah masuk dalam wilayah ini. PKI menyusup ke dalam kegiatankegiatan seni dan tradisi yang diselenggarakan oleh masyarakat. Kemudian dari keseniankesenian tersebut, sebagian besar masyarakat Brondong secara otomatis menjadi anggota PKI. Pak Mustaji menambahkan:

....sebenarnya yang terjadi masyarakat tidak menyadari jika mereka direkrut menjadi anggota karena pada awalnya hanya menyumbang saja jika ada kegiatan yang diselenggarakan oleh PKI baik berupa uang ataupun bahan makanan, tetapi kemudian mereka otomatis terdaftar menjadi anggota PKI yang resmi bahkan data-data mereka juga tercantum di dalam koran.

Pengaruh PKI yang sangat nyata di Brondong "merebut" perhatian dari para tokoh agama terutama dari golongan Muhammadiyah. Muhammadiyah baik di tingkat pusat maupun lokal bekerjasama dengan pemerintah Orde Baru, pada pasca peristiwa G30S/PKI memang mempunyai komitmen untuk memberantas PKI beserta kroni-kroninya. Bahkan, ketua Muhammadiyah saat itu, KH. Ahmad Badawi menyatakan dengan tegas bahwa Membubarkan PKI adalah Ibadah (Pasha dalam Rosyadi, 2008).

Jihad Muhammadiyah untuk memerangi PKI di kawasan Brondong didukung oleh masyarakat dan pemerintah setempat. Akan tetapi, menurut sebagian masyarakat, pemberantasan PKI di Brondong banyak yang tidak tepat sasaran atau dengan kata lain korban pembunuhan bukan anggota PKI yang sebenarnya.Pak Mustaji menuturkan:

Ada sinyalemen bahwa pembunuhan juga bisa dilakukan karena berdasar sentimen belaka (istilahnya: "guru gething"). Pembunuhan dilakukan oleh orang di daerah Paciran, Sedayu Lawas, dan Blimbing, dan kebanyakan dilakukan oleh orang Muhammadiyah. Mayat pembunuhan PKI dibuang di pambon istilahnya Kali Gebang, sebelah KUD. Selain peristiwa pembunuhan, ada anggota PKI lain yang dibuang ke Pulau Buru, tapi sudah dikembalikan kembali ke desa Brondong. Diantaranya adalah Pak Basir, Pak Kasmujud, dan Pak Kasturi. Kondisi masyarakat setelah itu masih mengalami ketakutan dan traumatis luar biasa, apalagi yang namanya tercantum dalam data-data PKI (Wawancara tanggal 11 Desember 2007).

Hal tersebut juga dibenarkan oleh Pak Kasdali yang mengatakan bahwa:

....orang Brondong banyak yang dibunuh itu. Padahal sebenarnya ada yang tidak terlibat menjadi anggota PKI sepenuhnya. Maka dari itu saya masih takut terhadap partai-partai saat ini, takut masih ada kaitan dengan PKI. Dan penyebab pembunuhan bisa bermacammacam, terkadang hanya karena "guru gething" (karena tidak suka saja) misalnya soal rebutan pacar (genda'an), banyak orang sini yang seperti itu. Tetapi karma juga berjalan kok mbak.

Motif pribadi diduga menjadi dasar terjadinya pembunuhan pascaperistiwa G30S/ PKI 1965. Motif pribadi yang dimaksud bisa berupa balas dendam karena persoalan wanita ataupun persoalan harta. Pak Yanto kembali menegaskan bahwa:

.... kembali lagi ke cerita masa lalu, PKI itu sendiri kan sampai sekarang kan masih belum jelas, sebelumnya PKI itu siapa orang apa... belum jelas tujuan bagaimana sampai sat ini kan masih kontroversi ya... begitu juga dengan yang ada di brondong barangkali dengan banyaknya orang terbunuh ya mbak ya dengan banyaknya orang terbunuh...ini klo saya masih belum yakin bahwa apakah itu PKI apakah itu hanya sekedar orangorang yang hanya melampiaskan dendamnya kepada orang yang tidak disukai..karena kita tidak tau persisnya seperti apa..barangkali kalo misalnya ketangkap terus diadili o kamu PKI lha itu baru saja.... tapi klo tiba-tiba dibunuh dengan banyaknya orang yang terbunuh tadi kan kita sendiri kan tidak tau...yang dibunuh ini yang PKI atau yang membunuh yang PKI... sampeyan sendiri juga nggak tau kan...orang Islam ini PKI ya mbak ya...Islam kan agama...nah...itu belum tentu punya pemikiran yang bagus... artinya belum tentu ya?... yang punya pemikiran positif dan mereka tidak pernah menaruh dendam dengan orang lain... (Wawancara tanggal 5 Oktober 2007).

Dengan demikian bisa disimpulkan bahwa peristiwa pembunuhan pada G30S/PKI di Brondong oleh tokoh Muhammadiyah di tingkat lokal, tidak hanya disebabkan karena pertentangan ideologi dan agama tetapi juga diwarnai oleh motif-motif pribadi. Hal inilah yang kemudian menjadi pemicu konflik laten antara golongan abangan dan golongan Muhammadiyah. Golongan abangan yang dimaksud adalah mayoritas 
masyarakat nelayan terutama yang bertempat tinggal di daerah Sentono, sedangkan golongan Muhammadiyah adalah kiai-kiai Muhammadiyah beserta santri dan pengikutnya yang mayoritas bertempat tinggal di daerah Karangasem.

\section{- Masa Pergerakan Sosial 1965}

Didik Rohmawan (Jawa Pos, 2007) menyatakan bahwa gerakan antikomunis pascaperistiwa G30S/PKI pada 1965 di Lamongan paling besar terjadi di wilayah pantura. "Pada 2 Oktober 1965 atau hanya sekitar 3 hari setelah peristiwa G30S/PKI di Jakarta, di wilayah pantura Lamongan (Kecamatan Paciran dan Brondong) gerakan anti-PKI sudah beraksi secara besar-besaran. Padahal jarak antara Jakarta dan Lamongan cukup jauh dan pada saat itu sarana komunikasi masih sangat terbatas. Peristiwa G 30 S/PKI 1965 ditandai sebagai momentum perubahan sosial bagi masyarakat Indonesia pada umumnya dan masyarakat Brondong pada khususnya. Di Brondong, perubahan sosial terjadi pada aspek sosial keagamaan dan budaya masyarakat secara keseluruhan.

Menurut Pak Mustaji, modin NU di daerah Sentono, ada perubahan yang sangat besar terjadi pada masyarakat Brondong pascaperistiwa G 30 S/PKI khususnya pada dimensi keagamaan. Beliau mengatakan setidaknya ada 5 komponen perubahan sosial keagamaan di Brondong. Pertama, jika dilihat dari jumlah tempat ibadah. Sebelum peristiwa G30S/PKI jumlah masjid hanya ada dua buah tetapi sekarang jumlahnya bertambah menjadi 6 mushola dan 11 masjid. Kedua, kuantitas orang yang beribadah ke masjid juga semakin banyak. Ketiga, di setiap masjid yang didirikan juga ada TPQ (Taman Pendidikan Al-Qur'an) sehingga semakin banyak pula jumlah anak-anak yang bisa mengaji di Brondong. Keempat, banyaknya sekolah Islam yang didirikan di Brondong meskipun semuanya milik yayasan Muhammadiyah. Kelima, terhapusnya budaya minuman keras dalam tradisi kesenian nelayan, seperti seni tayub.

Perubahan sosial yang terjadi pada masyarakat Brondong tentunya tidak lepas dari peran aktor perubahan. Menurut Kiai Afnan, perubahan sosial terjadi karena kedatangan golongan muda Muhammadiyah di Brondong setelah melakukan studi pada universitasuniversitas Islam maupun pondok pesantren baik di dalam maupun di luar Lamongan. Dakwah Muhammadiyah secara organisatoris, sebenarnya memang lebih memprioritaskan pada bidang sosial dan pendidikan. Hal inilah yang kemudian menjadi landasan bagi kiai-kiai Muhammadiyah untuk merubah nilai-nilai agama dan budaya pada masyarakat.

Selain tokoh-tokoh Muhammadiyah sebagai aktor perubahan, kiai NU juga berperan dalam perubahan sosial keagamaan khususnya di daerah Sentono. Kiai tersebut adalah Kiai Imron Marzuki. Kiai Imron berasal dari Desa Banjaranyar dan pada tahun 1968 mulai berdakwah di Brondong. Dakwah yang dilakukan oleh Kiai Imron adalah dakwah persuasif, mengajak individu-individu secara halus untuk beribadah, mendirikan mushola Al-Jihad di Sentono, dan mengajar mengaji bagi anak-anak serta masuk dalam budaya masyarakat.

Perubahan sosial dan keagamaan yang terjadi di Brondong adalah akibat masuknya ideologi keagamaan NU dan Muhammadiyah. Sosialiasi Muhammadiyah dilakukan melalui pendidikan formal (pendirian sekolah-sekolah keagamaan) dan non formal (dakwah keagamaan, pendirian TPQ, dan pendirian masjid dan mushola) atau dengan kata lain banyak menggunakan pendekatan struktural. Berbeda dengan Muhammadiyah, Kiai NU di Brondong lebih banyak menggunakan pendekatan kultural, mencoba beradaptasi dengan budaya masyarakat dan memasukkan nilai-nilai Islam di setiap tradisi lokal nelayan.

\section{- Masa Reformasi hingga Saat Ini}

Kiai Imron Marzuki yang dinilai sebagai figur kiai kharismatik oleh masyarakat Brondong khususnya di daerah Sentono, wafat pada tahun 2003. Kematian ini dianggap sebagai kematian figur kharismatik. Menurut Weber, kematian figur kharismatik akan melahirkan krisis kesinambungan dan cara menangani krisis ini sangat penting artinya bagi corak hubungan sosial selanjutnya (O’Dea, 1992).

Pascameninggalnya Kiai Imron Marzuki, masyarakat Brondong kehilangan figur tokoh agama yang menjadi teladan dan panutan. Makna kiai dan kesalehan sosial yang secara ideal terefleksikan di dalam diri Kiai Imron Marzuki menyebabkan masyarakat Brondong kesulitan untuk menemukan figur pengganti yang sepadan. Status ekonomi dan keagamaan ustaz-ustaz NU saat ini, di samping karena usia yang masih muda, dianggap belum layak untuk menjadi seorang kiai di Brondong khususnya di daerah Sentono. Kondisi ini menyebabkan masyarakat 
Brondong khususnya daerah Sentono kembali kehilangan identitas atau dengan kata lain proses identifikasi diri dengan lembaga-lembaga sosial tempat individu menjadi anggotanya belum menemukan momen internalisasinya.

Di samping itu, konflik antara Kiai Muhammadiyah dan golongan nelayan Brondong kembali memanas pascameninggalnya Kiai Imron Marzuki. Konflik yang terjadi merupakan akibat dari wasiat Kiai Imron Marzuki yang minta dimakamkan di sebelah masjid Al-Jihad Sentono bersebelahan dengan makam Mbah Buyut Sentono ditolak oleh Kiai Muhammadiyah. Kiai Muhammadiyah beralasan bahwa Kiai Imron Marzuki sebenarnya bukan seorang kiai, tetapi adalah mantan Pegawai Negeri Sipil (PNS) sebagai juru penerangan di Desa Banjaranyar dan "belum pantas" untuk dimakamkan bersebelahan dengan masjid Al-Jihad, Sentono. Di satu sisi, masyarakat Brondong percaya bahwa Kiai Imron Marzuki sebenarnya adalah masih keturunan dari Sunan Dradjat sehingga pantas jika dimakamkan di sebelah masjid Al-Jihad Sentono. Akhirnya, resolusi konflik ditempuh melalui jalan damai dan sepakat untuk memakamkan Kiai Imron Marzuki di sebelah masjid Al-Jihad Sentono.

\section{Tiga Budaya Nelayan}

\section{- Budaya Pesisir dan Budaya Islam}

Realitas objektif masyarakat nelayan Brondong meliputi tiga macam budaya. Yaitu, budaya Jawa Pesisiran, budaya Islam, serta budaya nelayan. Ketiganya akan coba dijelaskan secara singkat dan padat dalam tafsir dialektika historis masyarakat nelayan.

Pada masa Kerajaan Mataram (abad 17 M), daerah Jawa dibedakan ke dalam tiga kategori. Yaitu, negarigung, mancanegari, dan pesisiran. Negarigung adalah wilayah pusat pemerintahan kerajaan Mataram yaitu, kota Yogyakarta dan Solo. Disebut Negarigung ketika berfungsi sebagai kawasan pemerintahan. Dan, disebut Kota Negari ketika berfungsi sebagai ibukota kerajaan. Perbedaan keduanya adalah mengenai istilah kepemimpinan. Yogyakarta dipimpin oleh seorang sultan, sedangkan di Solo dipimpin oleh seorang sunan.

Disebut sultan dan sunan karena keduanya lekat dengan peradaban Islam. Menurut Robert Redfield (1982) peradaban yang dikembangkan di pusat wilayah kerajaan Mataram itu berkategori Peradaban Besar
(Tradisi Besar) sebagai ciri dasar dari kebudayaan keraton. Daerah-daerah yang ada di sekitar atau di luar pusat kerajaan disebut wilayah mancanegari. Dalam arti politik, daerah mancanegara merupakan daerah-daerah yang dipimpin oleh residen (bupati) yang berada di bawah kekuasaan kerajaan Mataram. Sementara itu, dalam arti kebudayaan, memiliki kemiripan dengan kebudayaan Jawa Negarigung tetapi dari segi kualitas peradabannya, termasuk Tradisi Kecil sehingga tidak sehalus peradaban kraton (Lombard, 1996).

Terdapat perbedaan antara karater masyarakat Jawa Mataraman dan Jawa Pesisiran. Etnis Jawa Mataraman yang dimaksud adalah Jawa yang berada di sekitar pusat kerajaan, seperti, Yogyakarta dan Surakarta, sedangkan Jawa pesisiran yang dimaksud adalah Jawa yang berada jauh dari pusat kerajaan bahkan mendekati pesisir pantai utara Jawa. Orang Jawa yang bertempat tinggal di Yogyakarta dan Surakarta cenderung bersifat normatif dalam memahami sistem nilai budaya Jawa. Orang Jawa konon dianggap orang nglungguhi (setia dan senang hati melaksanakan) kejawaannya.

Sehubungan dengan itu, terdapat anggapan di dalam masyarakat Jawa, bahwa dalam aspek kehidupan manusia yang meliputi aspek-aspek spiritual, mental, dan jasmaniah, dibutuhkan semacam pemurnian. Jika ada tingkah laku, tindakan, sikap, dan kata-kata kasar dari seseorang, maka yang bersangkutan akan dianggap durung (belum) Jawa, belum sepenuhnya Jawa (dalam arti, belum mampu untuk bertindak sebagaimana layaknya orang Jawa).

Orang Jawa adalah makhluk yang mistis, yang menggunakan cara-cara yang mistis untuk bersatu dengan alam. Oleh karena itu, dalam kesehariannya orang Jawa cenderung membenci pertentangan dan menghargai konsensus (harmoni). Di sisi lain, orang Jawa yang bertempat tinggal jauh dari pusat kerajaan (khususnya di daerah pesisir utara Pulau Jawa, seperti Tuban, Lamongan, Gresik, Surabaya, dan Sidoarjo) justru pemahamannya tentang sistem nilai budaya Jawa tampak pada kulit luarnya saja. Ini disebebkan mobilitas penduduk yang tinggi dan perkawinan antaretnis. Orang-orang yang tinggal di pesisir utara Pulau Jawa sering dianggap cenderung kasar dalam berperilaku dan bertutur kata.

Karakter terbuka, lugas, dan egaliter dalam masyarakat pesisir disebabkan oleh akar 
sosial yang beragam. Pertama, tata ruang fisik (lingkungan alam pantai) yang terbuka dan tata ruang sosial dalam melakukan relasi perdagangan mempengaruhi karakter masyarakat pesisir yang terbuka. Kedua, sifat lugas berasal dari pemahaman masyarakat pesisir terhadap maknakejujuran dan persamaan hak dan derajat manusia di hadapan Allah dalam ajaran agama Islam (Ricklefs, 1989). Sikap ini diekspresikan dalam kecenderungan umum, yaitu, berbicara langsung kepada pokok persoalan dengan menggunakan bahasa ngoko ataupun krama madya. Dengan kata lain, di dalam berinteraksi antar sesamanya, umumnya masyarakat Jawa Pesisir lebih menekankan pada substansinya, bukanlah pada cara mengekspresikannya seperti yang dilakukan oleh masyarakat Jawa Pedalaman (Jogja dan Solo) (Vooren, 1982). Ketiga, sikap egaliter masyarakat pesisir dipahami dari pemaknaan mereka terhadap ajaran tasawuf, yaitu "semua manusia mempunyai kedudukan yang sama di hadapan Tuhan, kecuali tingkat ketaqwaannya". Sehingga, status tokoh keagamaan, seperti, wali, ulama, atau kyai menempati level yang tinggi dalam pandangan masyarakat pesisir dibandingkan dengan status ekonomi ataupun status sosial pada umumnya.

\section{- Budaya Nelayan}

\section{a. Upacara Petik Laut dan Tutup Playang}

Upacara tradisi petik laut dan tutup playang adalah upacara yang diselenggarakan oleh nelayan. Tradisi tersebut diselenggarakan untuk menandai pergantian musim ikan, yaitu musim panen pada upacara petik laut dan musim paceklik pada upacara tutup playang. Panitia penyelenggara dari upacara petik laut dan tutup playang pun berbeda. Jika upacara petik laut dikoordinasi oleh Paguyuban Nelayan Gendhong (PNG) maka upacara tutup playang dikoordinasi oleh Rukun Nelayan (RN). Penyelenggaraan upacara petik laut di Brondong baru dilaksanakan pada beberapa tahun terakhir mengingat berdirinya Paguyuban Nelayan Gendong (PNG) yang juga masih sangat baru. Sementara itu, penyelenggaraan tutup playang untuk pertama kalinya, menurut Pak Yanto (57), mantan ketua Rukun Nelayan dan ketua RT di kawasan Sentono, sudah ada sejak masa kerajaan Mataram dan diajarkan langsung oleh Mbah Buyut Sentono.

Tutup playang itu juga nyambung dari cerita itu tadi bahwa pada saat nelayan dulu itu mengalami pacekliklah itu dulu memang ada nya mbah tadi mbah sentono tadi masyarakat kita diajak istilahnya itu kan diajak itu ya shalatlah..diajak oleh mbah... dan orangorang itu dikumpulkan mungkin karena tradisi mungkin disini itu masih kental masih kental dengan tradisi-tradisi hindu dulu itu masih sempat diadakan apa ini tutup playang yang menyembelih kepala lembu.... (Wawancara tanggal 5 Oktober 2007)

Rangkaian acara upacara tutup playang yang dilaksanakan sejak masa Mbah Buyut Sentono ternyata mengalami perubahan dari waktu ke waktu yang puncaknya terjadi pada masa pergerakan sosial. Menurut Pak Mardaub, ketua Rukun Nelayan Brondong saat ini, mengungkapkan bahwa pada masa PKI, upacara tutup playang identik dengan kesenianJawa (seperti wayang, ketoprak, ludruk) dan juga minuman keras. Kemudian setelah terjadi pembunuhan terhadap anggota-anggota PKI di Brondong atau pada masa G 30 S PKI, keseniankesenian Jawa tersebut mulai berkurang dan minuman keras dihapuskan. Acara tersebut dirubah ke bentuk yang lebih religius seperti pengajian dan ceramah agama.

....tutup playang itu ada sejak tiga puluh tahun yang lalu mbak tapi namanya dulu manganan, tapi setelah gestapu kesenian seperti itu banyak berkurang yang bertahan hanya di brondong saja. Alasannya orang yang tua takut dikatakan masih dianggap PKI, karena PKI dekat dengan kesenian dan yang muda tidak suka dengan kesenian itu, karena mereka berpindah ke band dan dangdut. Dan pada saat itu, orang berlombalomba beralih kepada agama, bagaimana untuk menghadap Yang Kuasa dengan lebih baik....(Wawancara tanggal 29 November 2007).

Menurut Pak Yanto, mantan Ketua Rukun Nelayan periode 2000-2004, meskipun banyak kesenian Jawa yang dihapuskan dari upacara tutup playang, ada satu yang tidak bisa ditinggalkan oleh nelayan Brondong yaitu tayub atau sindiran. Tayub adalah kesenian yang menampilkan beberapa penari perempuan dengan diiringi musik Jawa atau gamelan.

......brondong kan punya tradisi setiap tahun
itu kan mengadakan eeeh tutup playang itu
tadi ya... kegitan yang tidak bisa ditinggalkan
oleh masyarakat sini itu yang namanya
tandaan
...tayub...gambyongan... dulu banyak rangkaian-
rangkaian yang saya sampaikan ada


tumpengan, larung tumpeng ada kepala lembu... dan sekaligus penarinya atau tandaknya itu diarak di tengah laut... beserta gongnya... itu dulu saya masih kecil... itu...terus lama-lama yang model- model gitu ndak ada tetapi tandaknya tetepmasih eksis sampek sekarang masih ada.... (Wawancara tanggal 5 Oktober 2007)

Hal tersebut dibenarkan oleh Pak Mustaji, modin NU di daerah Sentono, beliau mengungkapkan bahwa sindiran atau tayub merupakan tradisi yang tidak bisa ditinggalkan oleh nelayan Brondong. Walaupun pada saat ini, tayub atau sindiran bisa berjalan beriringan dengan pengajian atau ceramah agama.

Kalo sindir tayub itu namanya kesenian... dibikin sindir kadang dibuat wayang kulit... kadang campur sari... pengajian... macemmacemlah pokoknya.... seneng apa itu... kadang juga apa itu karaoke bagi pemudapemuda.... karaoke, pengajian, campursari... tapi yang tayub itu kayaknya sulit dihilangkan orang sini itu ndak mau...mesti harus satu tahun sekali itu...ya ndak papa ditambahtambahi ada campursari ada wayang kulit tapi sindir harus ada...seakan-akan gitu... saya liat itu...ndak mau dirubah... ada karaoke... tambahan campursari atau apaapa itu... tambahan tapi sekarang mesti ada pengajian ada... (Wawancara tanggal 11 Desember 2007)

Meskipun penyelenggaraan upacara tutup playang di satu sisi didukung oleh sebagian besar masyarakat Brondong tetapi di sisi lain juga menimbulkan konflik antara nelayan dan tokoh agama. Hal ini akan dibahas pada bagian selanjutnya.

\section{b. Manganan di Makam Mbah Sentono}

Manganan merupakan upacara yang diadakan oleh rakyat kecil pedesaan secara sederhana kepada arwah orang yang berjasa dalam agama (wali-wali dan Nabi) dan masyarakat (leluhur desa, kiai dan lain sebagainya). Di Brondong, upacara manganan diperuntukkan khusus kepada Mbah Buyut Sentono, nenek moyang desa Brondong yang kemudian disebut sebagai manganan sentono atau sedekah bumi. Pelaksanaan manganan Sentono dilakukan setiap bulan delapan pada hari kamis malam jum'at di makam Mbah Buyut Sentono yang diikuti oleh sebagian besar nelayan terutama nelayan juragan di kawasan desa Brondong dan Blimbing. Tujuan dilaksanakan manganan Sentono khususnya bagi masyarakat nelayan Brondong, menurut Pak Mardaub adalah untuk memperoleh kesehatan dan keselamatan.

\begin{abstract}
....Itu bisa dikatakan setiap tahun setiap bulan 8 ada, tapi namanya tidak lagi manganan sentono tapi sedekah bumi.masih banyak yang ikut sampai blimbing juga ada yang ikut. Ada yang bawa tumpeng, makanan dan segala macem. Tetapi permintaannya juga minta keselamatan itu saja, kesehatan. Padahal kadang2 di daerah karangasem yang basis MD, ada juga yang segan untuk ikut, tetapi klo pas pada waktu sedekah bumi, masih banyak yang ikut.... (Wawancara tanggal 29 November 2007)
\end{abstract}

Sejalan dengan pernyataan Pak Mardaub, Pak Mustaji seorang modin NU dan sekaligus pemimpin dalam acara manganan sentono menuturkan bahwa manganan sentono bertujuan agar nelayan mendapat ikan yang melimpah pada saat melaut (along), karena manganan diibaratkan sama dengan sedekah dalam ajaran Islam.

...tujuannya gini pemahaman orang itu shadaqah supaya cari ikan itu dapat banyak gitu lo... diberi keselamatan dan dapat rejeki banyak... memberikan shadaqah kepada masyarakat umum.... yang punya mengeluarkan yang minta ya nggak apa-apa nanti sampai habis dibagibagikan... (Wawancara tanggal 11 Desember 2007)

Bentuk acara manganan sentono tidak lepas dari tradisi Islam NU dan abangan yaitu perpaduan antara nasi tumpeng dan pembacaan surat yasin dan tahlil. Secara mendasar, Tradisi nelayan yang bersifat komunal seperti upacara petik laut dan tutup playang serta manganan di makam Mbah Sentono merupakan tradisi yang mempunyai tujuan sebagai bentuk pengungkapan rasa syukur kepada Tuhan YME atas hasil yang diberikan, memohon kesehatan dan keselamatan serta memohon hasil tangkapan ikan yang berlimpah pada saat melaut (along) karena baik manganan diibaratkan sama dengan sedekah dalam ajaran Islam.

Konsistensi pelaksanaan upacara tutup playang sejak masa Kerajaan Mataram hingga saat ini menandakan bahwa terdapat eksistensi budaya leluhur yang terlembaga dan terhabitualisasi, meskipun terjadi penyesuaian-penyesuaian rangkaian acara di dalamnya akibat masuknya ideologi komunis dan ideologi keagamaan Muhammadiyah. 


\section{Agama Nelayan dalam Konstruksi Sosial Berger dan Luckmann}

Menekuni pengetahuan masyarakat nelayan Brondong terhadap agama tidak terlepas dari realitas historis yang menjelaskan bagaimana pengetahuan dikembangkan, dialihkan dan dipelihara dalam setiap konteks sosial tertentu. Sebagai realitas historis, agama tidak lepas dari kesejarahan manusia dan kehidupannya yang berada dalam ruang dan waktu (Susan, 2007).

Realitas historis agama di Brondong yang telah dipaparkan pada bagian sebelumnya mendeskripsikan tentang periodisasi perubahan ideologi di Brondong sejak masa Kerajaan Mataram hingga saat ini. Masa Kerajaan Mataram di Brondong ditandai dengan masuknya Mbah Buyut Sentono dengan membawa ajaran agama sekaligus budaya. Artinya terdapat perpaduan antara budaya dan agama atau yang biasa disebut sinkretisme. Sinkrestisme di Brondong diwujudkan dalam upacara tutup playang yang disosialisasikan langsung oleh Mbah Buyut Sentono dan terlembaga hingga saat ini.

Perubahan sosioreligius kembali terjadi ketika ideologi komunis atau PKI masuk ke dalam wilayah Brondong pada sekitar tahun 1950-an. Ideologi komunis menyusup ke dalam kegiatan kesenian dan budaya yang diadakan oleh nelayan Brondong. Hal ini menyebabkan masyarakat nelayan di Brondong mengalami kemerosotan etika, moral dan agama. Kondisi ini mengalami puncaknya ketika peristiwa G $30 \mathrm{~S} /$ PKI 1965 atau yang disebut sebagai masa pergerakan sosial. Pada masa tersebut, masyarakat nelayan Brondong mengalami trauma yang mendalam akibat pembunuhan yang dilakukan oleh pemerintah dan tokoh-tokoh Muhammadiyah terhadap orang-orang yang dianggap sebagai anggota PKI di Brondong. Perasaan trauma tersebut melahirkan krisis identitas sehingga komunitas keagamaan seperti Muhammadiyah dan NU mempunyai peluang untuk kembali mengeksternalisasikan ideologi keagamaan kepada masyarakat nelayan Brondong.

Perubahan konteks sosial dari masa Kerajaan Mataram hingga saat ini sebagai realitas historis ideologi keagamaan masyarakat Brondong membawa konsekuensipengetahuan tentang makna agama bagi nelayan. Dalam perspektif konstruksi sosial Peter L. Berger dan Thomas Luckmann, realitas historis dan sosiokultural merupakan bangunan realitas obyektif melalui proses eksternalisasi dan obyektivasi. Sedangkan, pengalaman intersubyektif nelayan Brondong dalam memaknai agama yang meliputi bagaimana para nelayan memaknai tradisi budaya, komunitas keagamaan serta kiai dan kesalehan sosial seperti yang telah dipaparkan sebelumnya merupakan realitas subjektif melalui proses internalisasi. Pengetahuan makna agama sebagai realitas obyektif dan realitas subjektif terus-menerus berhubungan secara dialektis.

Dialektika antara realitas objektif dan realitas subjektif nelayan Brondong dalam memaknai agama terus berubah sesuai dengan konteks sosial tempat ideologi muncul. Dengan kata lain, ada unsur kekuasaan yang berpengaruh terhadap pengetahuan keagamaan nelayan Brondong dari agen ideologi yang muncul di setiap periodisasi historis. Jika pada masa Kerajaan Mataram ideologi yang muncul adalah sinkretis, maka nelayan Brondong cenderung memaknai agama sebagai sesuatu yang sinkretis. Artinya bahwa agama dan budaya dipahami sebagai suatu yang sama, tidak ada perbedaan antara keduanya karena mempunyai tujuan yang sama, yaitu Tuhan YME.

Periode perubahan historis keagamaan di Brondong bergolak kembali pada masa komunis. Dalam periode ini, makna agama mengalami dekonstruksi karena digantikan dengan kesenian dan ritual budaya serta perilaku yang menyimpang. Dengan kata lain, agama tidak mempunyai agen dalam proses eksternalisasi dan objektivasi, sehingga agama kehilangan momen internalisasinya.

Pascaperistiwa G 30 S/PKI 1965, agama kembali dieksternalisasi dan diobjektivasi oleh ideologi keagamaan Muhammadiyah dan Nahdatul Ulama (NU). Dalam mengkonstruksi makna agama, nelayan Brondong cenderung mengikuti ideologi keagamaan baik Muhammadiyah maupun NU agar mempunyai identitas sebagai warganegara yang beragama. Identitas tersebut mutlak diperlukan pada masa tersebut agar tidak dianggap sebagai anggota PKI.

Kematian kharismatik kiai NU, konflik antara nelayan dan Kiai Muhammadiyah, munculnya modernisasi dan globalisasi adalah konteks sosial di Brondong pada saat ini sebagai realitas objektif. Sementara itu, pengetahuan agama sebagai realitas subjektif berarti menyangkut makna, interpretasi, dan relasi subjektif individu terhadap makna agama. Makna agama yang dikonstruksi oleh nelayan pada akhirnya bersifat pragmatis. Pragmatis dalam arti bahwa mereka 
percaya bahwa nilai kebenaran dalam suatu ajaran agamabergantung pada penerapannya sesuai dengan kepentingan. Hal ini dibuktikan dengan pemaknaan mereka terhadap:

- Tradisi nelayan merupakan simbol eksistensi budaya leluhur dan wujud pengungkapan rasa syukur kepada Tuhan YME. Di samping kedua makna tersebut, tradisi budaya nelayan juga bersifat empiris, yaitu memohon keselamatan ketika melaut dan memperoleh hasil tangkapan yang melimpah (along);

- Hilangnya signifikansi makna komunitas keagamaan bagi nelayan Brondong. Oleh karena itu, nelayan Brondong tidak tidak berafiliasi pada komunitas keagamaan manapun atau dengan kata lain netral. Hal tersebut dipengaruhi karena faktor:

(1) Faktor traumatis masa lalu pada masa PKI;

(2) Ketiadaan tokoh agama yang dapat dijadikan panutan (kematian kharismatik kiai NU);

(3) Pola pikir yang pragmatis: Misalnya, ketika nelayan ingin mengadakan upacara tutup playang ataupun manganan sentono yang di dalamnya terdapat pembacaan ayat suci Al-Qur'an dan ceramah agama, mereka melibatkan tokoh-tokoh keagamaan dari NU karena Muhammadiyah melarang kegiatan tersebut. Akan tetapi, jika nelayan ingin shalat tarawih maka mereka memilih Muhammadiyah, karena shalat tarawih di masjid Muhammadiyah jumlah rakaatnya lebih sedikit sehingga lebih singkat.

- Pandangan nelayan terhadap kiai dan kesalehan dipahami sebagai simbol akomodatif yang menjadi penyeimbang antara agama dan tradisi.

\section{Agama, Kekuasaan, dan Pragmatisme}

Pengetahuan nelayan Brondong atas makna agama tidak lepas dari ideologi dan agen yang ada pada setiap periode historisitas. Ideologi tersebut pada akhirnya berebut pengaruh dan menjadi konstruksi dominan. Pada gilirannya, fenomena kekuasaan ikut terlibat. Dalam perspektif Berger, kekuasaan mempunyai peranan penting dalam kehidupan sosial. Sehingga menurutnya, kekuasaan dalam masyarakat mencakup kekuasaan untuk menetapkan prosesproses sosialisasi yang sifatnya menentukan dan, dengan demikian, kekuasaan untuk membuat kenyataan. Jelasnya, benar dan salah, baik dan buruk, menjadi wewenang kekuasaan dalam menentukannya (Berger dalam Susan, 2007).

Dalam perspektif Bourdieu, Mbah Buyut Sentono, Kiai Imron Marzuki (NU), Kiai Afnan Anshori (Muhammadiyah), serta organisasi FPI merupakan agen-agen yang saling memperjuangkan modal-modal yang mereka miliki untuk berebut pengaruh dalam ranah masyarakat nelayan Brondong. Strategi investasi simbolik dan strategi pendidikan digunakan oleh agen untuk merebut ideologi keagamaan masyarakat nelayan.

Kiai Imron Marzuki yang dinilai sebagai figur kiai kharismatik oleh masyarakat Brondong khususnya di daerah Sentono, wafat pada tahun 2003. Kematian ini dianggap sebagai kematian figur kharismatik. Menurut Weber, kematian figur kharismatik akan melahirkan krisis kesinambungan dan cara menangani krisis ini sangat penting artinya bagi corak hubungan sosial selanjutnya.

Pascameninggalnya Kiai Imron Marzuki, masyarakat Brondong kehilangan figur tokoh agama yang menjadi teladan dan panutan. Makna kiai dan kesalehan sosial yang secara ideal terefleksikan di dalam diri Kiai Imron Marzuki menyebabkan masyarakat Brondong kesulitan untuk menemukan figur pengganti yang sepadan. Hal ini pula yang menjadi salah satu sebab mengapa pemaknaan masyarakat nelayan terhadap komunitas keagamaan adalah netral, atau dengan kata lain tidak berafiliasi dengan golongan manapun. Dominasi Muhammadiyah atas masjid dan musholla, keberadaan FPI, serta pelarangan atas seni tayub dan larung kepala sapi tidak berpengaruh terhadap ideologi dan agama yang dimaknai oleh nelayan untuk mengikuti ideologi Muhammadiyah, karena agama yang dijalankan nelayan harus selaras dengan tradisi, tidak terikat pada komunitas manapun, dan mendukung etos kerja mereka atau dengan kata lain bersifat pragmatis, meskipun secara struktural Muhammadiyah dapat dikatakan mayoritas tetapi secara kultural masyarakat nelayan Brondong lebih dekat dengan tradisi NU.

Dalam analisis strategi Bourdieu, Mbah Buyut Sentono dan Kiai Imron berhasil menggunakan strategi investasi simbolik untuk tetap meneguhkan agama masyarakat nelayan Brondong pada Islam yang bersorak kultural, sedangkan Kiai Afnan Anshori dan FPI lebih cenderung menggunakan strategi pendidikan untuk merubah ideologi keagamaan masyarakat yang lebih modern dan menjauhkan budaya 
Islam, budaya pesisir dan budaya nelayan dari unsur tahayul, bid'ah dan churafat.

\section{Kesimpulan}

Pengkajian mengenai agama nelayan dalam perspektif konstruksi sosial terhadap masyarakat Desa Brondong, Kecamatan Brondong, Kabupaten Lamongan, akan dipaparkan inti temuan-temuan yang disesuaikan dengan permasalahan penelitian yang dikemukakan pada bagian sebelumnya. Pertama, transformasi ideologi dan agama masyarakat Brondong bergantung pada konstruksi sosial yang terbentuk pada masa ke masa. Kontruksi tersebut melalui proses objektivasi (penanaman nilai dan norma keberagamaan oleh agen-agen yang berpengaruh di setiap masa), proses internalisasi (pemaknaan keberagamaan oleh para nelayan bergantung pada pengalaman dalam sosialisasi primer dan sekunder) serta proses ekternalisasi (pencurahan diri nelayan pada tindakan keberagamaan mereka). Oleh karena itu, konstruksi nelayan terhadap keberagamaan ditentukan oleh realitas pada masa Kerajaan Mataram, Masa sebelum G 30 S/PKI 1965, Masa Pergerakan Sosial G.30S/PKI 1965, dan Masa Reformasi hingga saat ini yang artinya terus dinamis dan bertransformasi.

Kedua, pengetahuan Nelayan Brondong atas makna agama tidak lepas dari ideologi dan agen yang ada pada setiap periode historisitas. Ideologi tersebut pada akhirnya berebut pengaruh dan menjadi konstruksi dominan. Pada gilirannya, fenomena kekuasaan ikut terlibat. Akan tetapi, fenomena kekuasaan Muhammadiyah di Brondong hanya menyentuh pada tataran struktural dan tidak pada level kultural. Dalam analisis arena produksi modal Bourdieu, kiai NU lebih cenderung menggunakan investasi simbolik sedangkan kiai Muhammadiyah menggunakan strategi pendidikan. Namun, kebutuhan Kebutuhan nelayan terhadap nilai-nilai tradisi budaya yang menggunakan cara-cara non empiris seperti larung kepala lembu dan manganan sentono tetapi mempunyai maksud empiris, yaitu untuk memenuhi kebutuhan duniawi. Nilai-nilai yang telah dieksternalisasi dan diobyektivasi oleh Mbah Buyut Sentono nampaknya telah melembaga dan terus-menerus diinternalisasi karena seiring sejalan dengan budaya nelayan. Sedangkan ajaran Muhammadiyah diamalkan oleh nelayan dalam tindakan yang sangat pragmatis.

\section{Daftar Pustaka}

Abdullah, Amin, M. (2000). Kata Pengantar Jalan Ketiga Pemikiran Islam. Yogyakarta: IRCiSoD.

Berger, Peter dan Luckmann, Thomas. (1990). Tafsir Sosial Atas Kenyataan Risalah tentang Sosiologi Pengetahuan. Jakarta: LP3ES.

Berger, Peter dan Luckmann, Thomas. (1990). Langit Suci. Jakarta: LP3ES.

Berger, Peter. (1994). Kabar Angin dari Langit (Makna Teologi dalam Masyarakat Modern). Jakarta: LP3ES.

Brooks, Ann. (1997). Posfeminisme dan Cultural Studies (Sebuah Pengantar Paling Komprehensif). Yogyakarta: Jalasutra.

Chambali, Achmad. (2001). Selayang Pandang Sejarah Brondong. Dokumentasi Kelurahan Brondong, Kecamatan Brondong, Lamongan.

Geertz, Clifford. (1992). Tafsir Kebudayaan. Yogyakarta: Kanisius.

Haryatmoko. (2003). Etika Politik dan Kekuasaan. Jakarta: Penerbit Buku Kompas.

Kamiruddin. (2011). "Fungsi Sosiologis Agama (Studi Profan dan Sakral Menurut Emile Durkheim)". Jurnal Toleransi Vol.3 No. 2, 2011.

Karnanta, Kukuh Yudha. (2013). "Paradigma Teori Arena Produksi Kultural Sastra: Kajian Terhadap Pemikiran Pierre Bourdieu”. Jurnal Poetika Vol. 1 No. 1, Juli 2013.

Koentjaraningrat. (1984). Kebudayaan Jawa. Jakarta: Balai Pustaka.

Kuntowijoyo. (2006). Budaya dan Masyarakat. Yogyakarta: Tiara Wacana.

Kusnadi. (2002). Konflik Sosial Nelayan Kemiskinan dan Perebutan Sumber Daya Alam. Yogyakarta: LKiS.

Kusnadi. (2007). Jaminan Sosial Nelayan. Yogyakarta: LKiS.

Kusumawanti, Nike. (2006). "Konstruksi Sosial Relasi Inter Etnis Masyarakat Tuban (Studi Mengenai Kohesivitas Etnis JawaTionghoa di Kota Tuban dalam perspektif Konstruksi Sosial)”. Skripsi pada Jurusan Sosiologi Fakultas Ilmu 
Sosial dan Ilmu Politik, Universitas Airlangga Surabaya.

Legenhausen, Muhammad. (1999). Satu Agama atau Banyak Agama (Kajian tentang Liberalisme dan Pluralisme Agama). Jakarta: Lentera.

Lombard, Denys. (1996b). Nusa Jawa Silang Budaya - Kajian Sejarah Terpadu. Jakarta: Gramedia. Jilid II. Terjemahan.

Maliki, Zainuddin. (2000). Agama Rakyat Agama Penguasa: Konstruksi tentang Realitas Agama dan Demokrasi. Yogyakarta: Yayasan Galang.

Mubyarto, dkk. (1984). Nelayan dan Kemiskinan (Studi Ekonomi Antropolgi di dua Desa Pantai. Jakarta: CV. Rajawali.

Muhadjir, Noeng. (1998). Metodologi Penelitian Kualitatif: Pendekatan Positivistik, Rasionalistik, Fenomenologi dan Realitas Metafisik, telaah Studi Teks dan Penelitian Agama. Yogyakarta: Rake Sarasin.

Moleong, Lexy. (1993). Metodologi Penelitian Kualitatif. Bandung: Remaja Rosdakarya.

Mulyana,Deddy dan Rakhmat Jamaluddin. (2001). Komunikasi Antar Budaya (Panduan Berkomunikasi dengan Orang-orang Berbeda Budaya). Bandung: Remaja Rosdakarya.

Nakamura, Mitsuo. (1983). Bulan Sabit Muncul dari Balik Pohon Beringin: Studi tentang Pergerakan Muhammadiyah di Kota Gede Yogyakarta. Yogyakarta: Gadjah Mada University.

O’Dea, Thomas. (1992). Sosiologi Agama (Suatu Pengenalan Awal). Jakarta: Rajawali Press.

Parera, Frans.M. (1990). Kata Pengantar Tafsir Sosial Atas Kenyataan PeterL.Bergerdan Thomas Luckmann. Jakarta: LP3ES.

Sastrapratedja. (1994). Kata Pengantar Kabar Angin dari Langit (Makna Teologi dalam Masyarakat Modern). Jakarta: LP3ES.

Salman, Darmawan. (2006). Jagad Maritim. Makassar: Ininnawa.

Schroeder, Ralph. (2002). Max Weber: tentang Hegemoni Sistem Kepercayaan. Yogyakarta: Kanisius.

Semedi, Pujo. (2003). Close To The Stone, Far from the Throne (The Story of a
Javannesse Fishing community. 1820s1990s). Yogyakarta: Benang Merah.

Shofan, Moh. (2006). Jalan Ketiga Pemikiran Islam. Yogyakarta: IRCiSoD.

Sudarmanto, JB. (1986). Agama dan Ideologi. Yogyakarta: Kanisius.

Sukidin, Basrowi. (2002). Metode Penelitian Kualitatif Perspektif Mikro. Surabaya: Insan Cendekia.

Syam, Nur, (2005). Islam Pesisir. Yogyakarta: LKiS.

Thohir, Mudjahidin. (2006). Orang Islam Jawa Pesisiran. Semarang: Fasindo.

Ritzer, George and Goodman J. Duglas. (2004). Teori Sosiologi Modern, Jakarta: Prenada Media.

Ritzer, George. (2003). Teori Sosial Postmodern. Yogyakarta: Kreasi Wacana.

Rosyadi, Arwan. (2006). "Tafsir Sosial Atas Jihad”. Skripsi pada Jurusan Sosiologi, Fakultas Ilmu Sosial dan Ilmu Politik, Universitas Airlangga Surabaya.

Russel, Bertrand. (2008). Bertuhan Tanpa Agama. Yogyakarta: Resist Book.

Woodward, Mark. R. (1999). Islam Jawa (Kesalehan Normatif versus Kebatinan). Yogyakarta: LKiS.

\section{Artikel dan Sumber dari Internet}

Andi Sukmono Kumba, Rekonseptualisasi Agama dalam Ruang Publik http://www. hupelita.com/baca.php?id=36281 diakses pada 15 April 2008.

Clifford Geertz (1960) dalam Yuda Kurniawan A, Tanggap Warsa Satu Suro Sebagai Tradisi Ritual Antara Mithos dan Media Komunikasi Sosial. http://yudakurniawan. multiply.com/journal/item/16, diakses pada 19 November 2007.

Didik Rohmawan, Finalis LKIR LIPI 2007. Jawa Pos tanggal 27 Oktober 2007 dalam http://www.jawapos.co.id/index.php?act $=$ detail_radar\&id $=177031 \& \mathrm{c}=87$, diakses tanggal 14 Januari 2008.

Erhambudi (2007) Keniscayaan Sekularisasi di Dunia Islam http://erhambudi.wordpress. com/2007/05/30/introduction/, diakses tanggal 15 April 2008 
George Ritzer (2005) dan Andrew Heyweed (1997) dalam Panimbang http:// panimbang.blogspot.com/2007/09/ pemikiran-tentang-kekuasaan_8630. html, diakses pada 23 Maret 2008 .

Hilman Latief (2005), Agama dan Ruang Publik, Antara Profanisasi dan Sakralisasi http:// 64.203.71.11/kompas-cetak/0502/26/ opini/ 1581754.htm diakses tanggal 15 April 2008

Moh. Shofan (2008) Masa Depan Sekularisme http://news.okezone.com/index.php/ ReadStory/2008/02/ 17/58/84214 diakses tanggal 15 April 2008
Nelayan Muara Badak Laksanakan Upacara Mappanre Tasi http://www.kutaikarta negara.com/news.php?id=1517 diakses pada tanggal 6 Mei 2008.

Susan, Novri. 2007. Sosiologi Pengetahuan: Teori Konstruksi Sosial dan Konflik (2007) http://socialpeace.wordpress.com/ 2007/11/19/teori-konstruksi-sosial-dankonflik/, Diakses pada tanggal 19 Maret 2008. 